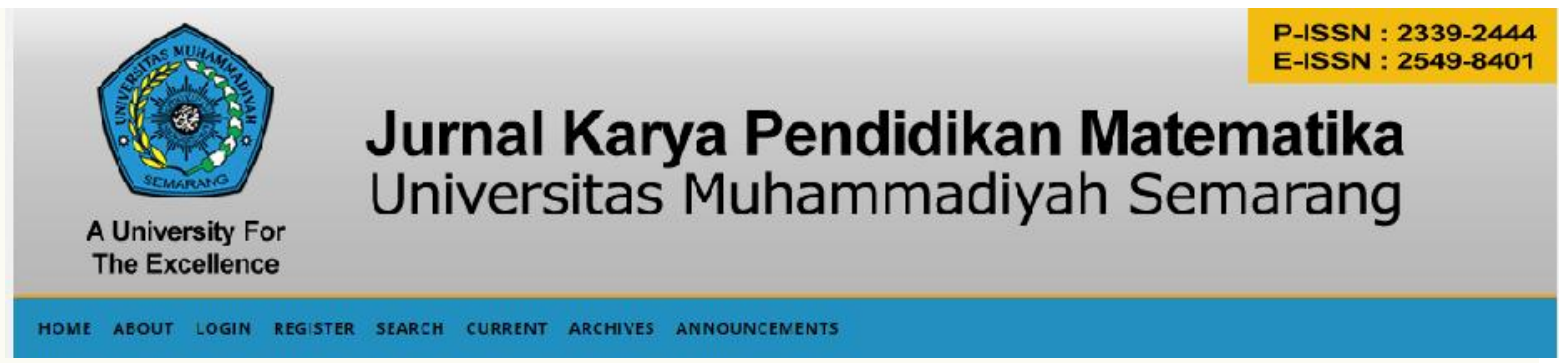

\title{
ANALISIS HASIL ASSESMEN DIAGNOSTIK KEMAMPUAN KOMUNIKASI MATEMATIKA SISWA PADA PEMBELAJARAN DIMENSI TIGA TIPE TPS KELAS X
}

\author{
Oleh: Sri Haryanti \\ sri15haryanti@gmail.com \\ SMA Negeri 15 Semarang
}

\begin{tabular}{|c|c|}
\hline Arti & Abstract \\
\hline : 10/9/2018 & \multirow{8}{*}{$\begin{array}{l}\text { This study aims to find out: the initial ability of students' mathematical } \\
\text { communication; TPS type learning process accompanied by diagnostic } \\
\text { analysis; analysis of student difficulties; effectiveness of TPS-type } \\
\text { learning accompanied by diagnostic analysis; and students' } \\
\text { mathematical communication skills after TPS type learning is } \\
\text { accompanied by diagnostic analysis. This type of research is mixed } \\
\text { methods with concurrent embedded research designs. Qualitative } \\
\text { methods as primary methods, while quantitative methods as secondary } \\
\text { methods. Samples in qualitative research were taken by purposive } \\
\text { sampling technique. Samples in quantitative research were taken by } \\
\text { cluster random sampling technique. The research data was collected } \\
\text { through questionnaires and written tests. Questionnaire data were } \\
\text { analyzed descriptively qualitatively and test data were analyzed by } \\
\text { proportion test, Uni Anova and Gain test. }\end{array}$} \\
\hline & \\
\hline : 20/9/2018 & \\
\hline & \\
\hline ratysts, & \\
\hline & \\
\hline & \\
\hline & \\
\hline
\end{tabular}

\section{Pendahuluan}

Mata pelajaran matematika perlu diberikan kepada semua peserta didik mulai dari sekolah dasar, untuk membekali peserta didik dengan kemampuan berpikir logis, analitis, sistematis, kritis, inovatif dan kreatif, serta kemampuan bekerjasama. Kompetensi tersebut diperlukan agar peserta didik dapat memiliki kemampuan memperoleh, mengelola, dan memanfaatkan informasi untuk hidup lebih baik pada keadaan yang selalu berubah, tidak pasti, dan sangat kompetitif. Dalam melaksanakan pembelajaran matematika, peserta didik harus dapat merasakan kegunaan belajar matematika.

Hasil belajar matematika ditinjau dari lima aspek yang dirumuskan National Council of Teachers of Mathematic (NCTM, 2000) menggariskan peserta didik harus mempelajari matematika melalui pemahaman dan aktif membangun pengetahuan yang dimiliki 
sebelumnya. Untuk mewujudkan hal itu , pembelajaran matematika dirumuskan dalam lima tujuan umum yaitu : (1) belajar untuk berkomunikasi; (2) belajar untuk bernalar; (3) belajar untuk memecahkan masalah; (4) belajar untuk mengaitkan ide; (5) pembentukan sikap positif terhadap matematika.Menurut NCTM (1989), kemampuan komunikasi matematika merupakan kemampuan siswa dalam menggunakan matematika sebagai alat komunikasi (bahasa matematika), dan kemampuan siswa dalam mengkomunikasi-kan matematika yang dipelajarinya sebagai isi pesan yang harus disampaikan.

Menurut Turmudi (2008:55),

komunikasi adalah bagian yang esensial dari matematika dan pendidikan matematika. Tanpa adanya komuni-kasi yang baik sangat sulit bisa mengembangkan matematika sebagaimana tujuan pembelajaran yang telah ditetapkan. Hal ini karena proses komunikasi akan membantu siswa dalam membangun makna, menyampaikan gagasan dengan benar, dan memudahkan dalam menjelaskan gagasangagasan tersebut kepada orang lain sehingga informasinya mudah dimengerti dan dipahami.

Komunikasi secara konseptual adalah memberitahukan dan menyebarkan berita, pengetahuan, pikiran-pikiran dan nilai-nilai dengan maksud untuk menggugah partisipasi agar hal-hal yang diberikan menjadi milik bersama. Secara umum komunikasi mengandung pengertian memberikan informasi, pesan, gagasan, ide, pikiran, perasaan kepada orang lain dengan maksud agar orang lain berpartisipasi, yang pada akhirnya informasi, pesan, gagasan, ide, pikiran, perasaan tersebut menjadi milik bersama antara komunikator (sumber) dan komunikan (penerima) (Soeharto, $2008: 11$ ).

Komunikasi adalah proses penyampaian makna dalam bentuk gagasan atau informasi dari seseorang kepada orang lain (Naim, 2011:18). Dalam setiap peristiwa komunikasi terkandung sejumlah unsur di antaranya pesan yang disampaikan, pihak-pihak yang terlibat dalam komunikasi tersebut, cara pengalihan atau penyampaian pesan serta teknologi yang dijadikan sarana. Pesan-pesan itu dapat berbentuk lisan maupun tulisan, dapat bersifat verbal maupun non verbal, Simbol-simbol yang disepakati tidak diucapkan tetapi disampaikan melalui cara atau alat selain kata-kata dan mempunyai makna yang dipahami oleh keduanya.
Untuk mencapai interaksi dalam belajar mengajar perlu adanya komunikasi yang jelas antara guru dan siswa. Banyak dijumpai kegagalan pada pembelajaran disebabkan oleh lemahnya komunikasi antara guru dan siswa. Jika siswa pasif dalam pembelajaran, guru tidak mengetahui kesulitan yang dihadapi masingmasing siswa. Untuk itulah guru perlu mengembangkan komunikasi yang efektif dalam proses pembelajaran.

Komunikasi secara umum dapat diartikan sebagai interaksi sosial melalui simbol dan sistem penyampaian pesan dari satu pihak kepada pihak lain agar terjadi pengertian bersama. Sedangkan kemampuan komunikasi matematis menurut Baroody (1993: 2-99) adalah kemampuan dalam matematika yang meliputi penggunaan keahlian: membaca, menulis, menyimak, menelaah, menginterpretasikan, dan mengevaluasi ide, simbol, istilah serta informasi matematika.

Komunikasi merupakan bagian penting dari matematika. Kosko dan Wilkins (2010: 81) menyatakan bahwa baik menulis maupun diskusi merupakan bagian integral dari komunikasi matematis yang dapat mempermudah pemahaman konsep matematika. Selain itu menulis juga dapat membantu peserta didik mengartikulasikan strategi sehingga dapat meningkatkan kemampuan kognitif. Sedangkan diskusi adalah wahana untuk memperdalam pemahaman konsep melalui interaksi sosial sehingga memungkinkan peserta didik lebih memahami konsep matematika.

Baroody (1993:2-107) mengungkapkan bahwa komunikasi adalah kemampuan peserta didik yang dapat diukur melaui aspek-aspek antara lain :Representasi (Representing), Mendengar (Listening), Membaca (Reading), Diskusi (Discussing) dan Menulis (Writing). Menurut NCTM (1989), kemampuan komunikasi matematika merupakan kemampuan siswa dalam menggunakan matematika sebagai alat komunikasi (bahasa matematika), dan kemampuan siswa dalam mengkomunikasi-kan matematika yang dipelajarinya sebagai isi pesan yang harus disampaikan. Menurut Kennedy dan Tipps (1994), kemampuan komunikasi matematika meliputi : penggunaan bahasa matematika yang disajikan dalam bentuk lisan, tulisan, atau visual; penggunaan representasi matematika yang disajikan dalam bentuk tulisan atau visual; dan penginterpretasian ide-ide matematika, 
menggunakan istilah atau notasi matematika dalam merepresentasikan ide-ide matematika, serta menggambarkan hubung-an-hubungan atau model matematika.Kemampuan komunikasi matematika yang akan diteliti pada penelitian ini adalah kemampuan komunikasi matematika tertulis menurut Kennedy dan Tipps dengan indikator yang disebutkan di atas.

Peran penting komunikasi matematis dirangkum oleh Asikin (2002: 22), yang menyatakan bahwa komunikasi matematis antara lain:dapat membantu mempertajam berpikir peserta didik; merupakan alat ukur pertumbuhan pemahaman peserta didik; dapat membantu peserta didik mengorganisasikan dan mengkon-solidasikannya; penting untuk mengkonstruksi pengetahuan matematika, mengembangkan pemecahan masalah dan meningkatkan penalaran, menumbuhkan rasa percaya diri, serta meningkatkan keterampilan sosial;sebagai alat yang sangat bermanfaat untuk membentuk komunitas matematika yang inklusif.

Kemampuan komunikasi matematika perlu menjadi fokus perhatian dalam pembelajaran matematika, sebab melalui komunikasi siswa dapat mengorganisasi dan mengonsolidasi berpikir matematikanya dan siswa dapat mengeksplorasi ide-ide matematika (NCTM, 2000). Pembiasaan memberikan argumen terhadap jawabannya, dan memberikan tanggapan terhadap jawaban orang lain akan menjadikan pembelajaran matematika lebih bermakna. Penyelesaian masalah matematika menjadi kurang bermakna apabila tidak dapat dipahami oleh orang lain. Oleh karenanya, peran komunikasi matematika menjadi sangat penting dalam pembelajaran matema-tika. Komunikasi matematika diperlukan oleh orang-orang untuk mengkomunikasikan gagasan atau penyelesaian masalah matematika, baik secara lisan, tulisan, ataupun visual, baik dalam pembelajaran matematika ataupun di luar pembelajaran matematika.

SMA 15 Semarang merupakan salah satu SMA negeri yang berada di daerah pinggiran. Siswa yang bersekolah di SMA 15 Semarang rata-rata memiliki kemampuan yang cukup, tidak ada yang menonjol dalam hal prestasinya. Berdasarkan pengalaman penulis sebagai pengajar di SMA 15 Semarang, kemampuan komunikasi matematika siswa di sekolah tersebut masih rendah. Hal ini dapat diamati pada saat kegiatan pembelajaran terutama dengan menggunakan model diskusi, kemampuan komunikasi siswa secara lisan masih rendah. Siswa cenderung pasif, yang aktif hanya siswa tertentu saja. Kemampuan komunikasi matematika tertulis dapat dilihat dari hasil studi pendahuluan kemampuan komunikasi matematika siswa, dengan mengambil materi sebelumnya yaitu materi Trigonometri. Dari hasil studi pendahuluan kemampuan komunikasi matematika siswa diperoleh hasil rata-rata kemampuan komunikasi matematika siswa sebesar 59,5. Ini menunjukkan bahwa kemampuan komunikasi matematika siswa masih rendah. Banyak siswa yang masih kesulitan dalam menginterpretasikan ide-ide matemati-kanya.

Sepanjang pengamatan penulis, pembelajaran matematika saat ini masih banyak yang menggunakan model ceramah, latihan dan drill (model konvensional), sehingga pembelajaran lebih banyak didominasi oleh guru. Hal ini kurang selaras dengan tujuan pembelajaran matematika dalam kurikulum KTSP. Oleh karena itu penulis mengajukan model pembelajaran kooperatif learning tipe TPS sebagai alternatif untuk meningkatkan kualitas pembelajaran matematika. Think Pair Share (TPS) adalah salah satu tipe pada pembelajaran model kooperatif learning. Pada pembelajaran tipe TPS ini, siswa menyelesaikan masalah secara berpasangan kemudian menshare hasilnya pada siswa lain.

Think Pair Share (TPS) adalah salah satu tipe pembelajaran model kooperatif learning. Pembelajaran kooperatif menurut Huda (2013:29) adalah pembelajaran kelompok yang diorganisir oleh satu prinsip bahwa pembelajaran harus didasarkan pada perubahan informasi secara sosial di antara kelompokkelompok pembelajar yang di dalamnya setiap pembelajar bertanggung jawab atas pembelajarannya sendiri dan didorong untuk meningkatkan pembelajaran anggota-anggota yang lain.

Arends (dalam Trianto, 2007) menyatakan bahwa Think Pair Share (TPS) merupakan suatu cara yang efektif untuk membuat variasi suasana pola diskusi kelas. Dengan asumsi bahwa semua resitasi atau diskusi membutuhkan pengaturan untuk mengendalikan kelas secara keseluruhan, dan prosedur yang digunakan dalam Think Pair Share dapat memberi siswa lebih banyak waktu berpikir, untuk merespon dan saling membantu. Melalui kegiatan diskusi ini, siswa diharapkan 
mampu saling membantu satu sama lainnya, sehingga menghasilkan efek positif terhadap peningkatan respon siswa. Guru hanya melengkapi penyajian singkat atau membaca tugas, atau situasi yang menjadi tanda tanya. Guru menginginkan siswa mempertimbang-kan lebih banyak apa yang dijelaskan dan dialami. Guru memilih menggunakan Think Pair Share untuk membandingkan tanya jawab kelompok secara keseluruhan. Dalam pembelajaran Think Pair Share, siswa secara tidak langsung dididik untuk berlatih berbicara di depan umum yaitu dengan jalan siswa mengutarakan ide atau pendapat dengan pasangannya.

Pembelajaran Think Pair Share (TPS) tumbuh dari penelitian pembelajaran kooperatif dan waktu tunggu. Pembelajaran kooperatif ini mula-mula dikembangkan oleh Frank Liman dkk dari Universitas Maryland pada tahun 1985. Startegi ini menantang asumsi bahwa seluruh resitasi dan diskusi perlu dilakukan didalam seting seluruh kelompok. Think Pair Share (TPS) merupakan suatu teknik sederhana dengan keuntungan besar. Think Pair Share (TPS) dapat meningkatkan kemampuan siswa dalam mengingat suatu informasi dan seorang siswa juga dapat belajar dari siswa lain serta saling menyampaikan idenya untuk didiskusikan sebelum disampaikan di depan kelas. Selain itu, Think Pair Share (TPS) juga dapat memperbaiki rasa percaya diri dan semua siswa diberi kesempatan untuk berpartisipasi dalam kelas. Think Pair Share (TPS) sebagai salah satu metode pembelajaran kooperatif yang terdiri dari 3 tahapan, yaitu thinking, pairing, dan sharing. Guru tidak lagi sebagai satusatunya sumber pembelajaran (teacher oriented), tetapi justru siswa dituntut untuk dapat menemukan dan memahami konsepkonsep baru (student oriented).

Penelitian yang dilakukan Kearney, NE. (2009) mendapatkan hasil bahwa komunikasi merupakan kemampuan dasar atau pokok dalam matematika. Hasil penelitian yang dilakukan Kabael (2012) menemukan bahwa kemampuan membaca (memahami) soal, menulis dalam bahasa matematika guru-guru matematika sekolah menengah yang masih baru tergolong lemah. Kemampuan berargumentasi (bernalar) dan pengetahuan struktur logika tidak cukup mendukung kemampuan matematika yang diharapkan. Guru-guru yang bertanggung jawab untuk mengembangkan kemampuan bernalar bagi siswanya ternyata tidak mengevaluasi makna kalimat matematika yang ditulisnya.
Penelitian yang dilakukan Prayitno (2013) ditemukan bahwa subyek laki-laki lebih unggul menyajikan jawaban secara tertulis secara lebih lengkap dan akurat, sedangkan subyek perempuan lebih jelas menyajikan jawabannya secara lisan atau verbal. Penelitian yang dilakukan Tandaliling (2011) menyatakan bahwa ada hubungan positif antara kemampuan komunikasi matematika siswa dengan belajar mandiri siswa. Penelitian yang dilakukan Koskow (2010) menemukan bahwa terdapat korelasi positif antara kemampuan komunikasi matematika dan kemampuan memanipulasi data, kemampuan diskusi dan kemampuan menulis.

Think Pair Share (TPS) adalah salah satu tipe pada pembelajaran model kooperatif learning. Pada pembelajaran tipe TPS ini ada tiga tahapan pokok, yaitu think (berpikir), pair (berpasangan) dan share (berbagi). Penelitian yang dilakukan Pandya (2011) menemukan bahwa rata-rata nilai post tes kelas yang menggunakan model pembelajatan think pair share lebih baik daripada nilai rata-rata kelas yang diajar secara konvensional, dan pembelajaran dengan model think pair share efektif. Penelitian lain yang dilakukan Kitaoka (2013) menemukan bahwa metode pembelajaran think pair share menjadi pemecah masalah yang efektif, yang meningkatkan motivasi siswa untuk belajardan keterlibatan mereka dalam belajar lebih lanjut, dan bahwa merupakan metode pengajaran yang efektif.

Model TPS yang diajukan penulis dalam penelitian ini disertai dengan analisis hasil penilaian diagnostik. Penilaian diagnostik adalah penilaian yang didasarkan dari hasil tes diagnostik. Menurut Brueckner dan Melby dalam Suwarto (2013 : 113), tes diagnostik digunakan untuk menentukan elemen-elemen dalam suatu mata pelajaran yang mempunyai kelemahan-kelemahan khusus dan menyediakan alat untuk menemukan penyebab kekurangan tersebut.

Ada beberapa tipe tes diagnostik : (1) The Compass Arithmetics Test, tes yang berguna untuk mencari kelemahan siswa berkenaan dengan berbagai unsur yang mendasari keseluruhan proses. (2) The Brueckuer Diagnostics Test, tes yang berguna untuk mencari kelemahan siswa berkenaan dengan pecahan dan sistem desimal.

Hughes dalam Suwarto (2013 : 113) menyatakan bahwa tes diagnostik dapat digunakan untuk mengetahui kekuatan dan 
kelemahan siswa dalam belajar. Tujuan penggunaan tes ini adalah untuk menentukan pengajaran yang perlu dilakukan di masa selanjutnya. Tes diagnostik adalah alat atau instrumen yang digunakan untuk mengidentifikasi kesulitan belajar.

Menurut Thorndike dan Hagen dalam Suwarto (2013 : 114), tes diagnostik pada intinya mencari kembali ke belakang tentang kesulitan yang muncul dan berkembang. Untuk menemukannya tidak bisa dilakukan dengan segera, diperlukan analisis kemampuan yang lengkap dan saksama.

Diagnosis dalam pendidikan merupakan konsep yang luas, meliputi identifikasi kekuatan dan kelemahan siswa. Diagnosis dilakukan untuk membantu guru dalam menentukan di mana proses belajar mengajar yang telah atau belum dikuasai. Diagnosis kesulitan belajar dilakukan untuk memahami jenis, karakterirtik dan latar belakang kesulitankesulitan belajar dengan menghimpun, mempergunakan berbagai data, informasi selengkap dan seobjektif mungkin sehingga memungkinkan untuk mengambil keputusan dan kesimpulan serta mencari alternatif kemungkinan pemecahannya. Dengan mengetahui kesulitan-kesulitan belajar siswa, seorang guru dapat menentukan rancangan tindak lanjut, yaitu dengan pembelajaran remedial bagi siswa-siswa yang nilainya masih di bawah batas tuntas.

Berdasarkan uraian di muka penulis berpendapat bahwa pembelajaran matematika konvensional kurang melibatkan siswa secara aktif. Pembelajaran berpusat pada guru, siswa cenderung pasif dan hanya menerima informasi yang disampaikan guru. Hal ini menyebabkan rendahnya kemampuan komunikasi matematika pada siswa. Pada pembelajaran matematika model TPS, siswa menyelesaikan suatu permasalahan melalui tiga tahap yaitu think (berpikir), pair (berpasangan) dan share (berbagi) . Guru hanya sebagai fasilitator, sedangkan siswa aktif untuk dapat menyelesaikan permasalahan tersebut. Selanjutnya dengan model TPS yang disertai analisis hasil penilaian diagnostik, dapat dirancang dan diimplementasikan tindakan yang tepat untuk meningkatkan kemampuan komunikasi matemati-kanya. Oleh karena itu peneliti bermaksud melakukan penelitian dengan judul: Analisis Hasil Penilaian Diagnostik Kemampuan Komunikasi Matematika Siswa pada Pembelajaran Dimensi
Tiga Tipe TPS. Dalam penelitian ini akan dijawab pertanyaan-pertanyaan mengenai : bagaimana kemampuan awal komunikasi matematika siswa; bagaimana proses pembelajaran tipe TPS yang disertai analisis diagnostik; bagaimana analisis kesulitan siswa; apakah pembelajaran tipe TPS yang disertai analisis diagnostik efektif; serta bagaimana kemampuan komunikasi matematika siswa setelah dilakukan pembelajaran tipe TPS yang disertai analisis diagnostik. Cakupan materi pembelajaran dalam penelitian ini adalah Dimensi Tiga untuk siswa kelas X.

\section{Metode}

Penelitian ini dilakukan di SMA Negeri 15 Semarang, Jl. Kedungmundu Raya No 34 Semarang. Penulis mengambil tempat penelitian ini dengan pertimbangan: (1) di sekolah tersebut kemampuan komunikasi matematika siswa masih rendah, (2) peneliti mengajar di sekolah tersebut. Penelitian ini dilaksanakan pada semester genap tahun pelajaran 2014/2015 yaitu sekitar bulan April 2015 sampai dengan bulan Mei 2015.

Jenis penelitian ini adalah mixed methods dengan desain penelitian concurrent embedded. Desain concurrent embedded merupakan metode penelitian yang menggabungkan antara metode penelitian kualitatif dan kuantitatif dengan cara mencampur kedua metode tersebut secara tidak seimbang (Sugiyono, 2013:537). Metode kualitatif sebagai metode primer, sedangkan metode kuantitatif sebagai metode sekunder. Sugiyono (2013: 490) menyatakan bahwa penelitian concurrent embedded ini juga dapat digunakan untuk pengembangan ilmu, pengembangan tindakan, dan pengembangan produk melalui Research and Development. Langkah-langkah penelitian desain concurrent embedded dengan metode kualitatif sebagai metode primer (Sugiyono, 2013:541) ditunjukkan pada Gambar 1 berikut ini. 


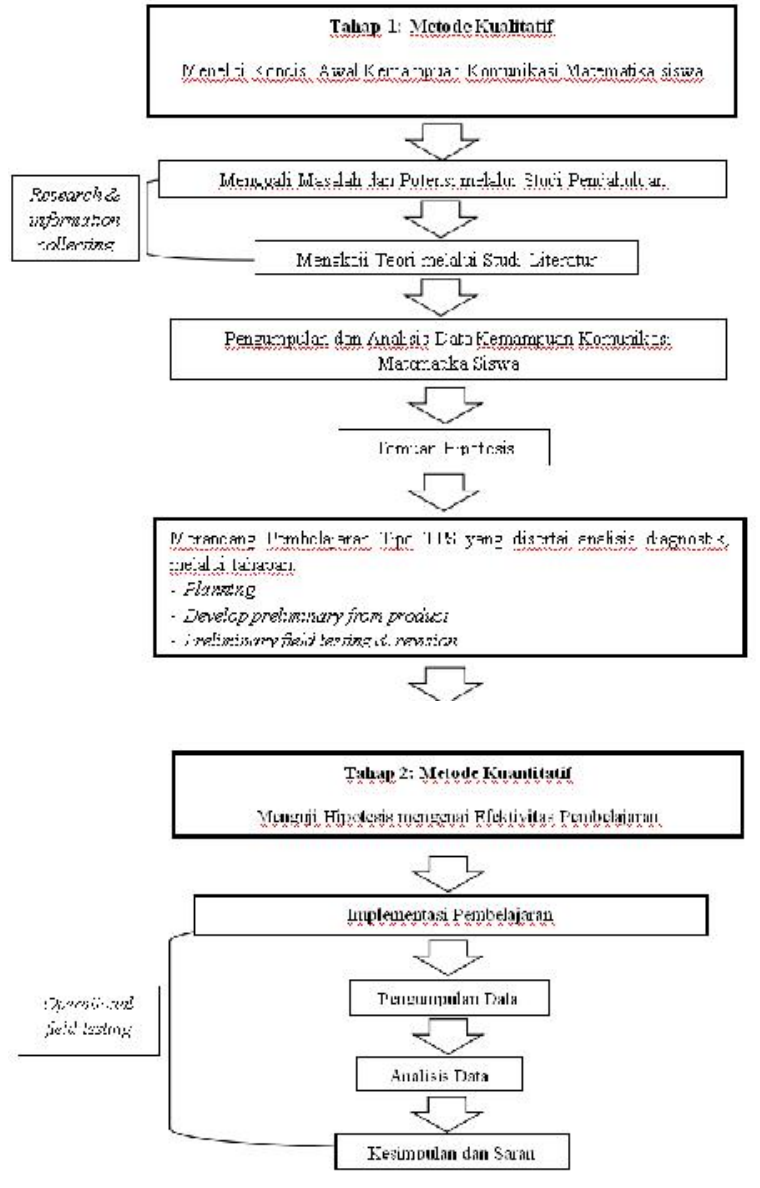

Gambar 1. Desain Penelitian

\section{Metode Kualitatif}

Menurut Moleong (2005:6) penelitian kualitatif adalah penelitian yang bermaksud untuk memahami fenomena tentang apa yang dialami oleh subjek penelitian, misalnya perilaku, persepsi, motivasi, tindakan, dan lainlain secara holistik dan dengan cara deskripsi dalam bentuk kata-kata dan bahasa, pada suatu konteks khusus yang alamiah dan dengan memanfaatkan berbagai metode alamiah.

Langkah awal penelitian kualitatif adalah menentukan setting penelitian yang di dalamnya terdapat masalah, atau potensi atau hanya ingin tahu di setting itu ada apa. Selanjutnya peneliti melakukan kajian teori prespektif yang berfungsi untuk memandu peneliti dalam mengumpulkan data dan analisis data, setelah itu peneliti masuk ke setting penelitian, melakukan pengumpulan data dan analisis data kualitatif, dan akhirnya peneliti dapat menemukan hipotesis (Sugiyono, 2013: 475). Pada penelitian kualitatif, data yang diteliti berupa kata-kata tertulis dan/atau lisan. Pendekatan deskriptif kualitatif digunakan untuk mendeskripsikan dan menggambarkan realitas mengenai suatu variabel, gejala, keadaan, atau fenomena sosial tertentu. Metode kualitatif dipilih dalam penelitian ini untuk menggali data, menganalis, dan mendeskripsikan kemampuan komunikasi matematika siswa.

Sampel diambil dengan menggunakan teknik purposive sampling . Sampel dalam penelitian ini adalah enam orang siswa kelas X, yaitu dua siswa kelas $\mathrm{X}$ yang dalam tes pendahuluan berada pada kelompok atas, dua siswa dari kelompok sedang, dan dua siswa pada kelompok bawah. Keenam orang siswa yang menjadi subjek penelitian akan diamati kemampuan komunikasi matematika pada pembelajaran Dimensi tiga dan dilakukan wawancara secara mendalam selama penelitian berlangsung.

Data dikumpulkan melalui observasi, wawancara mendalam dan dokumentasi. Observasi dilakukan terhadap proses pembelajaran dengan tipe TPS di kelas dan saat kegiatan wawancara dilaksanakan. Wawancara mendalam dilakukan secara terstruktur menggunakan instrumen pedoman wawancara. Dengan cara ini dapat digali hal-hal lebih mendalam mengenai komunikasi matematika subjek penelitian yang tidak bisa ditemukan melalui observasi. Selain itu hasil wawancara juga dapat digunakan untuk mengecek kredibilitas data observasi, apakah hal yang dilakukan oleh subjek penelitian yang diperoleh melalui hasil observasi cocok dengan apa yang sebenarnya dirasakan oleh subjek penelitian.

Teknik dokumentasi dalam penelitian ini digunakan untuk menghimpun data berupa: (1) foto, rekaman suara serta video kegiatan pembelajaran dan wawancara, (2) dokumen hasil pekerjaan siswa dalam kemampuan komunikasi matematika siswa, dan (3) catatan lapangan (field note) selama penelitian berlangsung.

Analisis data dilakukan sebelum di lapangan dan saat di lapangan. Sebelum di lapangan dilakukan analisis terhadap hasil observasi awal kegiatan pembelajaran. Hasil observasi awal berupa hasil komunikasi matematika siswa terpilih untuk materi Trigonometri di kelas X SMA Negeri 15 Semarang. 
Analisis data saat di lapangan dilakukan menurut model Miles dan Huberman yaitu : reduksi data, penyajian data dan penarikan kesimpulan/verifikasi. Tahap reduksi data pada penelitian ini dimulai dari menganalisis hasil pekerjaan tes pendahuluan siswa, yang kemudian digunakan untuk menentukan siswa yang akan dijadikan sebagai subjek penelitian. Selanjutnya hasil pengamatan dan wawancara terhadap subjek penelitian dianalisis berdasarkan rubrik yang telah dibuat kemudian disederhanakan menjadi susunan bahasa yang baik dan rapi. Data yang tidak diperlukan dalam penelitian di buang.

Penyajian data dalam penelitian ini digunakan untuk melihat gambaran kemampuan komunikasi matematika siswa. Penyajian data dilakukan dengan menyajikan dokumentasi yang dijelaskan melalui uraian singkat serta didukung penyajian bagan atau sejenisnya sehingga ditemukan kebermaknaan data untuk menyusun kesimpulan penelitian tahap pertama.

Langkah ketiga dalam analisis data kualitatif menurut Miles dan Huberman sebagaimana dikutip oleh (Sugiyono, 2010: 341) adalah penarikan kesimpulan dan verifikasi. Kesimpulan yang ditemukan pada tahap awal penelitian didukung oleh bukti-bukti yang valid dan konsisten saat peneliti kembali ke lapangan mengumpulkan data, maka kesimpulan tersebut dapat dipandang sebagai kesimpulan yang kredibel. Kesimpulan dalam penelitian kualitatif diharapkan merupakan temuan baru. Temuan dalam penelitian tahap pertama ini akan menjadi dasar action berupa pembelajaran untuk mengatasi permasalah yang akan dilakukan dengan metode kuantitatif.

Uji kredibilitas yang digunakan dalam penelitian ini ada tiga, yaitu peningkatan ketekunan dalam penelitian, triangulasi dan penggunaan bahan referensi. Peningkatan ketekunan yang dimaksud dalam penelitian ini adalah peneliti melakukan pengamatan secara cermat dan berkesinambungan. Cara tersebut dimaksudkan agar diperoleh kepastian data dan peristiwa yang dapat direkam secara pasti dan sistematis. Kegiatan yang dilakukan peneliti untuk meningkatkan ketekunan antara lain melakukan pengecekan kembalu apakah data yang telah ditemukan benar atau tidak, memberikan deskripsi data yang akurat dan sistematis tentang apa yang diamati.
Peneliti juga mempelajari referensi buku atau hasil penelitian dan dokumentasi yang terkait dengan temuan yang diteliti dengan maksud memperluas dan mempertajam wawasan peneliti sehingga dapat digunakan untuk memeriksa data yang ditemukan benar atau tidak. Uji kredibilitas lain yang digunakan adalah triangulasi. Triangulasi diartikan sebagai pengecekan data dari beberapa sumber dengan berbagai cara, dan berbagai waktu.

Data dari ketiga teknik yang digunakan tidak bisa dirata-ratakan seperti pada penelitian kuantitatif, melainkan dideskripsikan, dikategori-kan mana yang sama mana yang berbeda dan mana yang lebih. Uji kredibilitas dalam penelitian ini juga akan didukung dengan foto-foto, rekaman, dan dokumen autentik sehingga lebih dapat dipercaya.

\section{Metode Kuantitatif}

Langkah-langkah penggunaan metode kuantitatif adalah menentukan populasi dan sampel sebagai tempat untuk menguji hipotesis, mengembangkan dan menguji intrumen untuk mengumpulan data, analisis data dan selanjutnya membuat laporan yang diakhiri dengan kesimpulan dan saran (Sugiyono, 2013: 474-475).

Populasi penelitian ini adalah siswa kelas X IPA yang berjumlah 252 siswa. Pengambilan sampel dalam penelitian ini ditentukan dengan teknik cluster random sampling. Kelas X IPA 4 dengan jumlah siswa 36 ditetapkan sebagai kelas eksperimen dan kelas X IPA 5 dengan jumlah siswa 34 sebagai kelas kontrol.

Data penelitian dikumpulkan melalui angket atau kuosioner dan tes tertulis. Angket digunakan untuk mengetahui respon siswa terhadap pembelajaran matematika. Penyebaran kuesioner dilakukan kepada 70 siswa di kelas X IPA-4 dan X IPA-5.

Tes adalah serangkaian pertanyaan atau latihan atau alat lain yang digunakan untuk mengukur pengetahuan, intelegensi, kemampuan atau bakat yang dimiliki oleh individu atau kelompok (Arikunto, 2010: 193).Tes yang dilaksanakan dalam penelitian ini adalah tes kemampuan komunikasi matematika. Tes ini terdiri dari butir-butir soal 
uraian pada materi pokok Dimensi Tiga berbentuk uraian. Instrumen tes ini sebelumnya telah diujicobakan pada kelas yang telah ditentukan. Tes ini akan diberikan sebelum perlakuan sebagai pretes dan setelah perlakuan kepada kelas eksperimen dan kontrol sebagai postes. Hasil tes kedua kelas ini nantinya akan dibandingkan.

Sebelum tes digunakan soal tes kemampuan komunikasi matematika diujicobakan terlebih dahulu kemudian dilakukan uji validitas, uji reliabilitas, taraf kesukaran, dan daya pembeda. Soal-soal yang memenuhi kriteria dipilih untuk digunakan dalam penelitian.

Data hasil tes dianalisis dengan beberapa tahapan. Pada tahap awal dilakukan : Uji Normalitas, Uji Homogen-itas dan Uji Kesamaan Rata-Rata. Pada tahap akhir dilakukan : Uji Normalitas, Uji Homogenitas, Uji Hipotesis I (Uji Proporsi, Uji Hipotesis II (Uji Banding Rata-rata) dan Uji Hipotesis III (Uji Gain).

Uji hipotesis I digunakan untuk mengetahui persentase siswa kelas eksperimen yang tuntas individual pada kemampuan komunikasi matematika materi Dimensi Tiga sudah mencapai $75 \%$ atau belum. Uji hipotesis II dilakukan untuk mengetahui apakah terdapat perbedaan rata-rata kemampuan komunikasi matematika siswa kelas eksperimen dan kelas kontrol serta manakah yang lebih baik antara rata-rata kemampuan komunikasi matematika siswa kelas eksperimen atau kelas kontrol. Oleh karena itu digunakan uji t satu pihak. Uji Hipotesis III (Uji Gain) digunakan untuk mengetahui peningkatan kemampuan komunikasi matematika.

\section{HASIL PENELITIAN PEMBAHASAN}

\section{Hasil Penelitian}

Pada hasil penelitian ini dipaparkan tentang hasil dan analisisnya, yang terdiri dari analisis kemampuan awal komunikasi matematika, analisis proses pembelajaran tipe TPS disertai analisis diagnostik, analisis kesulitan kemampuan komunikasi matematika dan analisis efektifitas pembelajaran TPS disertai analisis diagnostik. Analisis kemampuan awal komunikasi matematika antara kelompok eksperimen dan kelompok kontrol relatif sama. Pada kelompok eksperimen, rata-ratanya 61,7 dengan nilai tertinggi 75 dan terendah 48 , sedangkan pada kelompok kontrol diperoleh rata-rata 61,1 dengan nilai tertinggi 69 dan terendah 48 . Dilihat dari sebaran data menunjukkan bahwa kemampuan awal komunikasi matematika masih di bawah kriteria ketuntasan minimal (KKM), yaitu 70.

Temuan tersebut didukung oleh hasil kuosioner. Sebanyak 3\% siswa memberikan respon sangat rendah, $67 \%$ memberikan respon rendah, $29 \%$ memberikan respon tinggi dan $1 \%$ memberikan respon sangat tinggi. Hal ini mengandung pengertian bahwa pembelajaran pada materi sebelumnya yaitu pembelajaran ekspositori kurang diminati siswa.

Proses pembelajaran tipe TPS disertai analisis diagnostik pada materi Dimensi Tiga dilakukan 4 kali pertemuan. Pertemuan pertama membahas tentang jarak dengan menggunakan LKS 1, pertemuan kedua membahas tentang proyeksi menggunakan LKS 2, pertemuan ketiga tentang sudut menggunakan LKS 3, dan pertemuan keempat tes kemampuan komunikasi matematika. Pada tiap pertemuan dilaksanakan dengan tahapan : membuka pelajaran, pre tes, think, pair, share dan diakhiri dengan penarikan kesimpulan dan pos tes. Bimbingan guru diberikan pada kelompok yang mengalami kesulitan. Kualitas pembelajaran diamati dengan hasil untuk pengamat 1 memberikan nilai $93,33 \%$ dan pengamat 2 memberikan nilai $82,22 \%$, sedang persentase rata-rata kedua pengamat adalah $87,78 \%$, berarti disimpulkan pembelajaran telah dilaksanakan dengan sangat baik.

Hasil angket respon guru menunjukkan bahwa : Kualitas perangkat pembelajaran sangat baik, kelayakan perangkat pembelajaran sangat baik, nilai rata-rata respon guru adalah 4,57 dengan kategori sangat baik, perangkat dan instrumen membantu dalam tugas mengajar, model pembelajaran TPS dapat dijadikan model pembelajaran utama dalam kegiatan belajar mengajar matematika, hambatan yang ditemui adalah perbedaan pemikiran dan kemampuan peserta didik dalam menganalogikan dan menganalisis masalah, keuntungan yang diperoleh adalah analogi benda-benda yang dekat dengan kehidupan 
sehari-harinya akan mempermudah peserta didik dalam menganalisis dan menyelesaikan soal-soal aplikasi.

Suasana pembelajaran tentang aktivitas siswa di kelas eksperimen diamati oleh dua orang pengamat. Pengamatan dilakukan 3 kali pertemuan. Nilai rata-rata suasana pembelajaran yang dihasilkan adalah 4,48. Nilai tersebut terletak di antara 4,20 dan 5,00 yang berarti suasana pembelajaran pada kelas eksperimen termasuk kategori sangat baik.

Respon siswa dari analisis angket menunjukkan respon positif (rata-rata 74,53\%) yang dikategorikan tinggi. Persiapan menjelang pelajaran, persiapan tes, kehadiran, semangat, tanggapan terhadap Buku Siswa dan LKS, kesediaan mengerjakan tugas, serta ketepatan waktu siswa tergolong tinggi $(75,35 \%)$. Siswa merasa senang $(71,88 \%)$, menganggap TPS sebagai hal yang baru $(90,63 \%)$ serta tertarik pada Buku Siswa dan LKS $(73,44 \%)$.

Efektivitas pembelajaran TPS disertai analisis diagnostik dapat dilihat dari hasil uji peningkatan kemampuan komunikasi setelah pembelajaran, hasil uji ketuntasan dan hasil uji perbedaan rata-rata kemampuan komunikasi antara kelompok eksperimen dan kelompok kontrol. Pengujian hipotesis ini diawali dengan uji normalitas sebagai uji prasyaratnya.

Normalitas suatu data dapat dilihat dari hasil uji Kolmogorov Smirnov, apabila diperoleh nilai signifikansi $>0,05$, dapat disimpulkan bahwa data berdistribusi normal. Hasil uji normalitas data diperoleh nilai signifikansi untuk data pretes sebesar 0,744 dan data postes sebesar 0,528. Karena nilai signifikansi $>0,05$, dapat disimpulkan bahwa data berdistribusi normal, sehingga statistik parametrik dapat dilanjutkan dalam pengujian hipotesis selanjutnya.

Peningkatan kemampuan komunikasi dapat dilihat dari hasil uji paired sample t-test. Pada kelompok eksperimen setelah dilakukan pembelajaran TPS mengalami peningkatan kemampuan komunikasi matematika yang signifikan, terbukti dari hasil uji t dengan nilai $t_{\text {hitung }}=12,704>t_{\text {tabel }}=1,692$. Rata-rata kemampuan komunikasi matematika sebelum pembelajaran sebesar 61,7 meningkat menjadi 76,1. Pada kelompok kontrol juga mengalami peningkatan kemampuan komunikasi matematika yang signifikan, terbukti dari hasil uji t diperoleh $t_{\text {hitung }}=7,699>t_{\text {tabel }}(1,690)$.
Secara kualitas peningkatan kemampuan komunikasi matematika setelah pembelajaran dapat dilihat dari gain ternormalisasi. Pada kelompok eksperimen, sebanyak $74 \%$ siswa mampu meningkat komunikasi matematika yang tergolong sedang, selebihnya $26 \%$ meningkat rendah. Kondisi sebaliknya terjadi pada kelompok kontrol, mayoritas siswa (72\%) masih mengalami peningkatan yang rendah, selebihnya $28 \%$ meningkat sedang.

Ketuntasan kemampuan komunikasi matematika dapat dilihat dari hasil uji mean dengan $\mu \mathrm{o}=76(\mathrm{KKM})$. Nilai $\mathrm{t}_{\text {hitung }}$ untuk 0,154 dengan nilai signifikansi $0,878>0,05$, yang berarti bahwa rata-rata sebesar 76,1 tidak berbeda nyata dengan $\mu$ o $=76(\mathrm{KKM})$. Hal ini menunjukkan bahwa perolehan rata-rata kemampuan komunikasi matematika pada kelompok eksperimen sudah sama dengan $\mathrm{KKM}=76$. Berbeda dengan kelompok kontrol, diperoleh $t_{\text {hitung }}=-6,181$ dengan signifikansi $0,000<0,05$, yang berarti bahwa secara signifikan rata-rata kemampuan komunikasi matematika sebesar 69,2 berbeda nyata dengan $\mu \mathrm{o}=76$ (KKM). Dengan demikian dapat disimpulkan bahwa rata-rata kemampuan komunikasi matematika pada kelompok kontrol masih di bawah KKM = 76 .

Perbedaan kemampuan komunikasi matematika antara kelompok eksperimen dan kelompok kontrol dapat dilihat dari hasil independent sample $\quad \mathrm{t}$-test. Nilai $\mathrm{t}_{\text {hitung }}=$ 5,358 dengan sign $=0,000,0,05$, yang berarti bahwa ada perbedaan kemampuan komunikasi matematika antara kelompok eksperimen dan kelompok kontrol. Dilihat dari nilai rata-ratanya menunjukkan bahwa kemampuan komunikasi matematika pada kelompok eksperimen lebih dari kelompok kontrol.

Dalam penelitian ini, kemampuan komunikasi matematika siswa dilihat dari dua aspek, yaitu tertulis dan lisan. Pada aspek tertulis, proses penyelesaian siswa dalam mengerjakan soal menjadi acuan. Sementara itu aspek komunikasi lisan dapat dilihat selama proses pembelajaran, yaitu dengan mengamati selama diskusi berlangsung, baik secara kelompok maupun klasikal.

Subyek penelitian sebanyak 6 orang dari tingkat kemampuan komunikasi matematika yang berbeda, yaitu 2 subyek penelitian dari tingkat kemampuan komunikasi matematika rendah, 2 subyek penelitian dari tingkat kemampuan komunikasi matematika sedang, 
dan 2 subyek penelitian dari tingkat kemampuan komunikasi matematika tinggi.

Indikator kemampuan komunikasi matematika yang digunakan dalam penelitian ini adalah siswa dapat (1) mengekspresikan ide-ide matematika melalui tulisan dan mendemonstrasi-kannya serta menggambarkannya secara visual; (2) memahami, menginterpretasikan, dan mengevaluasi ide-ide matematika secara tertulis, maupun dalam bentuk visual lainnya; (3) menggunakan istilah-istilah, notasi-notasi matematika dan struktur-strukturnya untuk menyajikan ide-ide, menggambarkan hubungan-hubungan dengan model-model situasi. Hasil analisis kesulitan kemampuan komunikasi matematika tersebut dilihat dari 3 tes yaitu postes 1 , portes 2 dan postes 3 .

Analisis kesulitan kemampuan komunikasi matematika untuk materi jarak suatu titik ke garis dan bidang (postes 1) dipaparkan dengan grafik berikut ini.

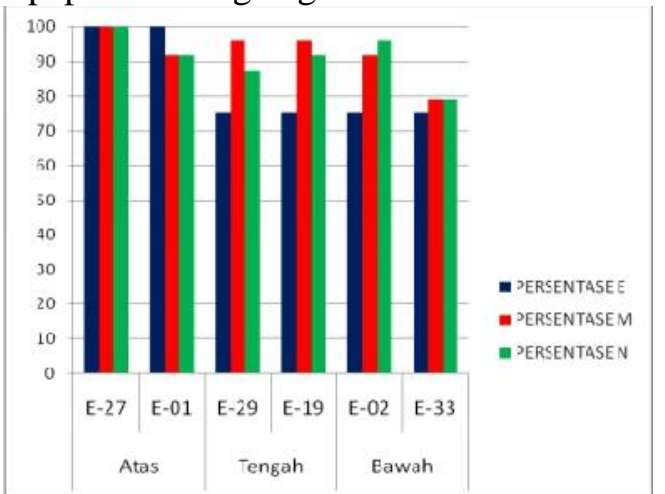

Gambar 2. Analisis Komunikasi Matematika pada Postes 1

Keterangan:

E : Mengekspresikan ide-ide matematika, mendemonstrasikan serta menggambarkannya secara visual

M: Memahami, menginterpretasi dan mengevaluasi ide-ide matematika.

$\mathrm{N}$ : Menggunakan istilah-istilah, notasinotasi matematika dan struktur-strukturnya untuk menyajikan ide-ide.

Berdasarkan grafik di atas dapat disimpulkan ada kecenderungan siswa di kelompok atas memiliki kemampuan mengekspresikan ide-ide matematika, mendemostrasi-kan serta menggambarkannya secara visual lebih tinggi daripada siswa di kelompok tengah dan bawah.

Analisis kesulitan kemampuan komunikasi matematika untuk materi panjang proyeksi garis pada bidang (postes 2) dipaparkan dengan grafik berikut ini.

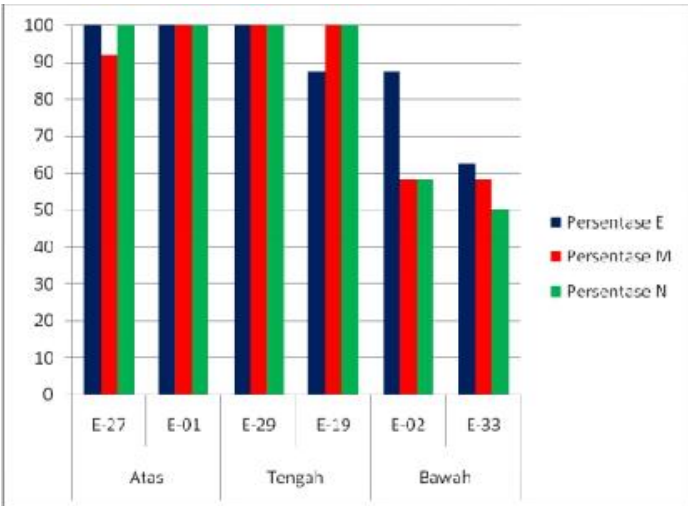

Gambar 3. Analisis Komunikasi Matematika pada Postes 2

Bedasarkan grafik di atas siswa pada kelompok atas dan tengah cenderung memiliki kemampuan mengekspresikan ide-ide matematika, mendemonstrasikan serta menggambarkannya secara visual, memahami, menginterpretasi dan mengevaluasi ide-ide matematika dan menggunakan istilah-istilah, notasi-notasi matematika dan strukturstrukturnya untuk menyajikan ide-ide berkaitan dengan proyeksi garis pada bidang lebih baik daripada siswa di kelompok bawah.

Analisis kesulitan kemampuan komunikasi matematika untuk materi sudut dalam ruang dimensi (postes 3) dipaparkan dengan grafik berikut ini.

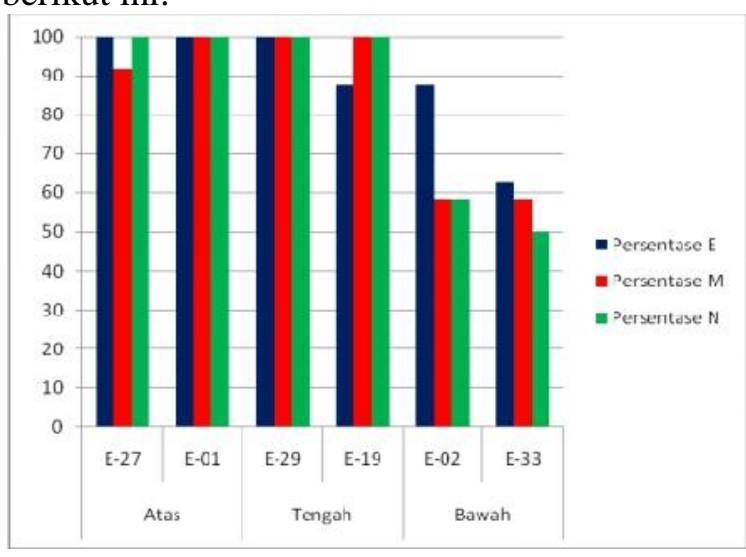

Gambar 4. Analisis Komunikasi Matematika pada Postes 3

Gambar 4 memperlihatkan bahwa siswa pada kelompok atas dan tengah cenderung memiliki kemampuan mengekspresikan ide-ide matematika, mendemonstrasikan serta meng-gambarkannya secara visual, memahami, menginterpretasi dan mengevaluasi ide-ide matematika dan menggunakan istilah-istilah, notasi-notasi matematika dan struktur-strukturnya untuk menyajikan ide-ide berkaitan dengan sudut 
pada ruang dimensi tigas lebih baik daripada siswa di kelompok bawah.

Kemampuan komunikasi matematika per indikator dapat dilihat dari hasil pretes ditunjukkan Tabel 1.

Tabel 1. Hasil Analisis Kemampuan Komunikasi Matematika

\begin{tabular}{|c|c|c|c|c|}
\hline No & Aspek & $\begin{array}{c}\text { Kelompok } \\
\text { tinggi }\end{array}$ & $\begin{array}{c}\text { Kelompok } \\
\text { Sedang }\end{array}$ & $\begin{array}{c}\text { Kelompok } \\
\text { rendah }\end{array}$ \\
\hline$\overline{1}$ & $\begin{array}{l}\text { Kemampuan } \\
\text { mengelkspresi- } \\
\text { kan ide-ide } \\
\text { matematika } \\
\text { melalui tulisan } \\
\text { den } \\
\text { mendemonstrasi } \\
\text { kannya serta } \\
\text { menggambarkan } \\
\text { nyasecrar } \\
\text { visual }\end{array}$ & 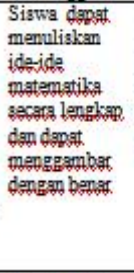 & 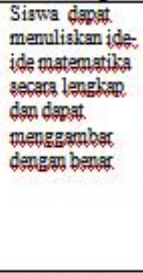 & 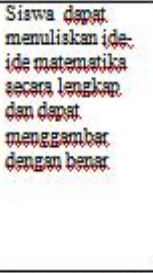 \\
\hline$\overline{2}$ & $\begin{array}{l}\text { Kemampuan } \\
\text { menshami, } \\
\text { menginterpretasi } \\
\text { lan, dan } \\
\text { mengevaluasi } \\
\text { ide-ide } \\
\text { matematika } \\
\text { secars tertulis, } \\
\text { msupun dalam } \\
\text { bentulk visual } \\
\text { lainnya }\end{array}$ & 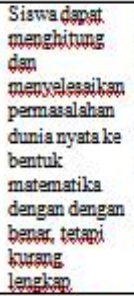 & 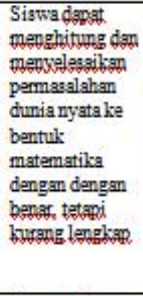 & $\begin{array}{l}\text { Siswa tidal dapgt } \\
\text { menghitung dan } \\
\text { menvelesgiksn } \\
\text { permasalahan } \\
\text { dunia nyata ke } \\
\text { bentuk } \\
\text { matematiks } \\
\text { dengan bener. }\end{array}$ \\
\hline$\overline{3}$ & $\begin{array}{l}\text { Kemampuan } \\
\text { dalam } \\
\text { menggunaksm } \\
\text { istilah-istilah, } \\
\text { notasi-notasi } \\
\text { matematika dan } \\
\text { struktur- } \\
\text { struktumya } \\
\text { untul } \\
\text { menyajikan ide- } \\
\text { ide, } \\
\text { menggamberkan } \\
\text { hubungan- } \\
\text { hubungan } \\
\text { dengan model- } \\
\text { model situasi. }\end{array}$ & $\begin{array}{l}\text { Siswa culus } \\
\text { mampu } \\
\text { merepresentasi } \\
\text {-kan permass- } \\
\text { lahan dalam } \\
\text { bentulk gambar } \\
\text { (bangun datar, } \\
\text { bangun ruang) } \\
\text { lengksp } \\
\text { dengan } \\
\text { katerangan } \\
\text { unsur bangun } \\
\text { ruang untuk } \\
\text { menudahksm } \\
\text { dalam } \\
\text { menyele- } \\
\text { saikan masalah }\end{array}$ & $\begin{array}{l}\text { Siswa culhop } \\
\text { mampu } \\
\text { merepresentasi- } \\
\text { lan permass- } \\
\text { lahan dalam } \\
\text { bentuk gambar } \\
\text { (bangun datar, } \\
\text { bangun ruang) } \\
\text { lenghas dengan } \\
\text { keterangan } \\
\text { unsur bangun } \\
\text { rang untuk } \\
\text { memudahlsan } \\
\text { dalam menyele- } \\
\text { saikan masalah }\end{array}$ & $\begin{array}{l}\text { Siswa tidals } \\
\text { mampu } \\
\text { merepresentasi- } \\
\text { kan permass- } \\
\text { lahan dalam } \\
\text { bentulk gambar } \\
\text { (bangun datar, } \\
\text { bangun ruang) } \\
\text { lengksp dengan } \\
\text { keterangan unsur } \\
\text { bangun ruang } \\
\text { untul } \\
\text { memudahkan } \\
\text { dalam menyele- } \\
\text { saiksn masalah }\end{array}$ \\
\hline
\end{tabular}

\section{Pembahasan}

\begin{abstract}
Komunikasi matematika merupakan bagian penting dalam pembelajaran matematika. Melalui komunikasi, siswa dapat memperjelas ide-ide matematika dan menghubungkan antar konsep. Komunikasi juga sebagai alat bantu berpikir, menemukan pola, menarik kesimpulan, menyelesaikan masalah dan sebagai sarana interaksi antar siswa serta antara guru dan siswa. Fachrurazi (2011) menyatakan bahwa komunikasi matematika merefleksikan pemahaman matema-tika. Para siswa belajar matematika seakan-akan mereka menulis dan berbicara dengan apa yang ia kerjakan. Mereka terlibat secara aktif untuk menyelesaikan permasalahan matematika.
\end{abstract}

Komunikasi matematika memerlukan peran aktif dari siswa. Siswa harus terlibat dalam proses pembelajaran. Model pembelajaran yang selama ini diberikan oleh guru cenderung bersifat teacher centered, siswa cenderung pasif dan kurang dilibatkan dalam pembelajaran. Hal ini berpengaruh terhadap kemampuan komunikasi matematika yang rendah, terbukti dari rata-rata sebesar 61,7, dengan nilai tertinggi 75 dan terendah 48 . Rendahnya kemampuan komunikasi matematika juga dapat dilihat dari respon siswa sebelum pembelajaran. Siswa cenderung memberikan respon kurang terhadap matematika, terbukti sebanyak $47 \%$ siswa memberikan respon rendah. Rendahnya respon siswa tersebut dipengaruhi oleh beberapa faktor, misalnya guru yang mengajar, model pembelajaran yang dipakai dan media yang digunakan. Rendahnya komunikasi matematika tersebut menuntut perubahan kualitas pembelajaran yang dilakukan. Melalui penelitian ini diterapkan pembelajaran Think, Pair dan Share (TPS).

Pembelajaran TPS ini terdiri dari tiga tahapan yaitu tahap Think, Pair dan Share. Pada tahap Think, pembelajaran memberikan kesempatan kepada siswa untuk berpikir sendiri-sendiri. Mereka berpikir untuk bisa menyelesaikan permasalahan matematika. Mereka merencanakan langkah-langkah untuk menyelesaikan permasa-lahan matematika. Siswa dari kelompok atas dapat merencanakan penyelesaian permasalahan matematika dengan baik. Siswa dari kelompok tengah dapat menuliskan langkah-langkah penyelesaian, tetapi kurang lengkap. Sedangkan siswa dari kelas bawah masih kesulitan dalam menuliskan langkah-langkah penyelesaian soal matematika.

Tahap berikutnya adalah Pair, di mana pada tahap ini siswa bekerja berpasangan untuk menyelesaikan permasalahan matematika. Pada tahap ini siswa harus terlibat aktif dalam diskusi. Siswa yang bisa menjawab pertanyaan menyampaikan pendapatnya, siswa lain mendengarkan penjelasan dari temannya. Diskusi dapat berjalan dengan lancar, walaupun ada beberapa siswa dalam kelompok diskusi yang cenderung pasif. Siswa yang berasal dari kelompok rendah cenderung diam, pasif, tetapi tidak mendominasi kelompok, sehingga diskusi tetap berjalan dengan baik dan lancar.

Tahap terakhir dari TPS adalah Share, di mana perwakilan kelompok yang ditunjuk maju untuk menyelesaikan permasalahan matematika. Siswa yang berasal dari kelas tinggi cenderung berani menyampaikan pendapatnya di depan teman-temannya. Sedangkan siswa yang berasal dari kelas rendah membantu dalam menggambar. Walaupun 
dalam satu kelompok berasal dari kelas tinggi, sedang dan rendah, namun mereka saling bekerja sama dan saling membantu sehingga presentasi berjalan lancar.

Pembelajaran TPS memerlukan peran aktif dari siswa. Menurut Cheng (2011: 79), pada pembelajaran matematika guru harus mampu meningkatkan keterlibatan siswa selama proses pembelajaran berlangsung baik di dalam kelas maupun di luar kelas dan mengurangi kecenderungan guru dalam mendominasi proses pembelajaran. Hal ini dapat diamati dari aktivitas siswa pada saat pembelajaran berlangsung. Aktivitas siswa diamati dengan 20 indikator yang ada di lembar aktivitas siswa. Dari hasil pengamatan aktivitas siswa selama 3 pertemuan diperoleh hasil bahwa aktivitas siswa sangat baik. Hal ini menunjukkan bahwa siswa aktif selama proses pembelajaran dengan model TPS.

Pembelajaran dikatakan efektif jika: (1) kemampuan komunikasi matematika siswa pada pembelajaran TPS tuntas, ketuntasan klasikal lebih dari atau sama dengan $75 \%$ dengan mencapai kriteria ketuntasan minimal KKM adalah 70 ; (2) rata-rata kemampuan komunikasi matematika kelas pada pembelajaran TPS lebih baik daripada kelas dengan pembelajaran ekspositori; (3) terdapat peningkatan kemampuan komunikasi matematika pada pembelajaran TPS.

Berdasarkan hasil analisis data postes diperoleh gambaran bahwa kemampuan komunikasi pembelajaran TPS yang memenuhi kriteria ketuntasan minimal. Hal ini menunjukkan bahwa kemampuan komunikasi matematika siswa pada kelas dengan pembelajaran TPS yang sudah mencapai kriteria ketuntasan minimal yaitu 70 mencapai lebih dari $75 \%$. Rata-rata kemampuan komunikasi matematika mencapai 76,1 dan secara klasikal hasil uji ketuntasan dengan $\mathrm{KKM}=70$ diperoleh nilai signifikansi $0,878>$ 0,05 , yang berarti bahwa ketuntasan kemampuan komunikasi matematika. Dibandingkan dengan kelompok kontrol dengan rata-rata 69,2 menunjukkan bahwa kemampuan komunikasi matematika kelas pada pembelajaran TPS lebih baik daripada kelas dengan pembelajaran ekspositori, terbukti dari hasil uji $\mathrm{t}$ sebesar 5,358 dengan nilai signifikansi $0,000<0,05$. Pembelajaran TPS juga berdampak pada peningkatan kemampuan komunikasi matematika, terbukti dari $\mathrm{t}_{\text {hitung }}=$ $12,704>\mathrm{t}_{\text {tabel }}=1,692$. Hal ini sejalan dengan penelitian Danebeth (2012), Shefali Pandya (2011) mengatakan bahwa penerapan model pembelajaran kooperatif tipe Think Pair Share (TPS) memberikan pengaruh yang signifikan terhadap kinerja kelompok dalam pembelajaran jika dibandingkan dengan pembelajaran konvensional. Penelitian serupa juga dilakukan oleh Rohman (2011:33) bahwa rata-rata nilai pemahaman konsep matematis siswa yang mengikuti model pembelajaran kooperatif tipe TPS lebih tinggi dari rata-rata nilai pemahaman konsep matematis siswa yang mengikuti pembelajaran konvensional. Hasil sama juga diungkapkan Urip Tisngati (2011: 87) penelitiannya mendapatkan hasil bahwa pada materi fungsi pembelajaran kooperatif pembelajaran TTW dan TPS lebih baik dari konvensional.

Hasil perhitungan indeks gain menunjukkan adanya peningkatan kemampuan komunikasi matematika siswa dengan skor mean gain sebesar 0,34 pada kriteria sedang. Sebanyak $74 \%$ siswa mampu meningkat komunikasi matematika yang tergolong sedang. Keberhasilan ini disebabkan karena pendidikan matematika realistik menekankan pentingnya eksplorasi fenomena kehidupan sehari-hari. Pengetahuan informal yang diperoleh siswa dari kehidupan sehari-hari digunakan sebagai permasalahan kontekstual untuk dikembangkan menjadi konsep formal matematika serta siswa terlibat secara interaktif, menjelaskan, dan memberikan alasan pekerjaannya memecahkan masalah kontekstual, memahami pekerjaan temannya, menjelaskan dalam diskusi kelas sikapnya setuju atau tidak setuju dengan solusi temannya, menanyakan alternatif pemecahan masalah, dan merefleksikan solusi-solusi itu (Bakker, 2004).

Tes diagnostik adalah tes yang diberikan untuk mengetahui kesulitan belajar yang dihadapi siswa (Suwarto, 2013). Dengan mengetahui kesulitan yang dihadapi siswa, seorang guru dapat menentukan tindakan atau langkah berikutnya pada proses pembelajaran. Dalam penelitian ini tes diagnostik diberikan setiap akhir pembelajaran yang berupa soal pos tes yang berbentuk uraian. Dari hasil jawaban siswa pada pos tes 1 , pos tes 2 dan pos tes 3 dapat dianalisis kesulitan yang dihadapi siswa pada indikator kemampuan komunikasi matematika yang mana.

Kemampuan mengekspresikan ide-ide matematika, mendemonstrasikan serta menggam-barkannya secara visual untuk 
kelompok tinggi pada pos tes 1 sudah sangat baik. Pada pos tes 2 kemampuan mengekspresikan ide-ide matematika, mendemonstrasikan serta menggambarkannya secara visual ini masih tetap sangat baik. Demikian juga pada pos tes 3 kemampuan mengekspresikan ide-ide matematika, mendemon-strasikan serta menggambarkannya secara visual ini masih tetap sangat baik. Mereka sudah dapat menggambar dengan baik dan benar menggunakan penggaris. Dari permasalahan matematika mereka bisa menggambarkan bangun ruangnya.

Kemampuan memahami, menginterpretasi dan mengevaluasi ide-ide matematika untuk kelompok tengah pada pos tes 1 cukup baik. Pada pos tes 2 sangat baik. Sedang pada postes 3 kemampuan memahami, menginterpretasi dan mengevaluasi ide-ide matematika juga sangat baik. Mereka dapat mengerjakan soal tetapi kurang lengkap atau jawabannya masih salah.

Kemampuan menggunakan istilah-istilah, notasi-notasi matematika dan strukturstrukturnya untuk menyajikan ide-ide untuk kelompok rendah pada postes 1 cukup baik, pada pos tes 2 kurang dan pada pos tes 3 juga masih kurang. Mereka kebanyakan kurang memperhatikan notasi-notasinya tetapi langsung memasukkan berupa angka-angka.

Setelah dilakukan pembelajaran dengan model TPS, siswa diukur kemampuan komunikasinya dengan pos tes. Hasil pos tes dianalisis berdasarkan tiga indikator kemampuan komunikasi matematikanya. Dari hasil pos tes diperoleh hasil bahwa siswa dari kelompok atas, tengah maupun bawah memiliki kemampuan mengekspresikan ide-ide matematika, mendemon-strasikan serta menggambarkannya secara visual dengan sangat baik. Semua siswa dapat menggambar dengan benar dan menggunakan penggaris. Mereka dapat menggambarkan secara visual dari permasalahan matematika yang diberikan.

Kemampuan memahami, menginterpretasi dan mengevaluasi ide-ide matematika pada kelompok atas dan kelompok tengah cukup baik, tetapi untuk kelompok bawah masih kurang. Kelompok atas dan tengah dapat menjawab soal walaupun kurang lengkap atau salah perhitungannya. Sedangkan kelompok bawah tidak dapat menjawab soal.

Kemampuan menggunakan istilah-istilah, notasi-notasi matematika dan strukturstrukturnya untuk menyajikan ide-ide pada kelompok atas dan kelompok tengah cukup baik, tetapi untuk kelompok bawah masih kurang. Kelompok atas dan tengah dapat menuliskan notasi-notasi matematika walaupun tidak semuanya ditulis. Sedangkan kelompok bawah tidak dapat menuliskan notasi-notasi matematikanya. Mereka langsung menghitung tanpa menulis notasi-notasi yang dipakai.

Secara umum kemampuan komunikasi matematika dengan menggunakan model TPS lebih baik dari model pembelajaran konvensional. Hal ini sejalan dengan penelitian yang dilakukan oleh Wina Sanjaya (2006) bahwa hal yang menarik dari model pembelajaran kooperatif adalah adanya harapan selain memiliki dampak pembelajaran, yaitu berupa peningkatan prestasi belajar siswa (student achievement) juga mempunyai dampak pengiring seperti relasi sosial, penerimaan terhadap siswa yang dianggap lemah, harga diri, norma akademik, dan suka memberi pertolongan.

Berdasarkan hasil uji paired sample t-test diperoleh kesimpulan bahwa pembelajaran matematika dengan TPS dapat meningkatkan kemampuan komunikasi matematika yang lebih baik daripada pembelajaran konvensional. Uji mean menunjukkan bahwa pembelajaran matematika dengan TPS dapat membantu siswa mencapai ketuntasan belajar. Keefektifan model TPS untuk pemecahan masalah juga ditemukan dalam penelitian Sri Mukti Ayu Wandira dkk (2017).

Pembelajaran matematika dengan Think Pair Share (TPS) efektif untuk membuat variasi suasana pola diskusi kelas. Prosedur yang digunakan dalam Think Pair Share dapat memberi siswa lebih banyak waktu berpikir, untuk merespon dan saling membantu. Siswa selalu memiliki waktu lebih banyak untuk berpikir dalam merespon suatu pertanyaan. Perlunya waktu bagi siswa untuk mampu berkomunikasi ilmiah sesuai dengan temuan Putri dkk (2017) bahwa siswa reflektif yang lambat menjawab namun benar mampu berkomunikasi ilmiah lebih baik daripada siswa impulsif, yang cepat menjawab tetapi salah.

Melalui kegiatan diskusi ini, siswa mampu saling membantu satu sama lainnya, sehingga menghasilkan efek positif terhadap peningkatan respon siswa. Guru hanya melengkapi penyajian singkat atau membaca tugas, atau situasi yang menjadi tanda tanya. Kegiatan berkelompok saling membantu yang ditemukan dalam penelitian ini sesuai dengan temuan 
Anintya dkk (2017) pada model pembelajaran resourced based learning. Pentingnya saling membantu untuk meningkatkan kemampuan komunikasi ilmiah juga ditemukan pada penelitian Ambarwati (2015) dan Oktaviani (2015);

Guru yang memilih menggunakan Think Pair Share membandingkan tanya jawab kelompok secara keseluruhan. Dalam pembelajaran Think Pair Share, siswa secara tidak langsung berlatih berbicara di depan umum yaitu dengan jalan siswa mengutarakan ide atau pendapat dengan pasangannya. Kemampuan berkomunikasi ilmiah erat hubungannya dengan percaya diri siswa. Semakin tinggi rasa percaya diri siswa semakin tinggi pula kemampuan berkomunikasi ilmiah. Hal ini sesuai juga dengan hasil penelitian Sapto dkk (2015) dan Ambarwati dkk (2015).

Semakin tinggi level siswa semakin tinggi pula kemampuan berkomunikasi matematika dan semakin sedikit hambatan belajar yang dialaminya. Hal ini juga ditemukan pada penelitian Permata dkk (2015) dan Latifah (2015). Kemampuan komunikasi matematika juga dapat ditingkatkan jika siswa memanfaatkan seluruh indera (Fauziah dkk, 2017) dan merasakan beragam pengalaman belajar matematik (Setyaningsih dkk, 2016).

\section{Simpulan}

Berdasarkan hasil penelitian ini, diperoleh simpulan sebagai berikut: 1) Kemampuan awal komunikasi matematika siswa pada materi Dimensi Tiga kelas X SMA N 15 Semarang masih di bawah kriteria ketuntasan minimal karena respon yang rendah terhadap pembelajaran yang dilakukan; 2) Proses pembelajaran tipe TPS yang disertai analisis diagnostik pada materi dimensi Tiga kelas $\mathrm{X}$ dilakukan melalui tiga tahap think-pair-share. pada tahap think, siswa diberikan kesempatan untuk berpikir secara mandiri menyelesaikan tugas. Pada tahap pair, siswa diberikan kesempatan untuk berpasangan berdiskusi menyelesaikan permasalahan. Pada tahap share, siswa diberikan kesempatan menyampaikan gagasan di dalam kelompok maupun di kelas; 3) Pembelajaran tipe TPS yang disertai analisis diagnostik pada materi Dimensi Tiga kelas $\mathrm{X}$ efektif, terbukti dari komunikasi matematika yang mencapai ketuntasan, meningkat dan secara signifikan lebih baik dari kelompok kontrol; 4) Kesulitan sebagian besar siswa dalam kemampuan komunikasi matematika dengan pembelajaran tipe TPS pada materi Dimensi Tiga kelas $\mathrm{X}$ adalah kurang memperhatikan notasi dan kurang teliti dalam menghitung; 5) Kemampuan komunikasi matematika siswa setelah dilakukan pembelajaran tipe TPS yang disertai analisis diagnostik pada materi Dimensi Tiga kelas X. pada kelompok atas, tengah dan bawah sudah mampu mengekspresikan ide-ide matematika, sudah dapat menggambar sesuai dengan permasalahan yang diberikan dan menulis notasi matematika masih kurang.

Pembelajaran think pair share secara sigifikan memberikan dampak pada ketuntasan, peningkatan kemampuan komunikasi matematika serta lebih baik daripada pembelajaran ekspositori dan sebagai implikasinya maka pembelajaran think pair share dapat diterapkan dengan memberikan kesempatan untuk berpikir menyelesaikan masalah, berpasangan berdiskusi dan mempresentasikan hasil diskusi di kelas. Di setiap kegiatan pembelajaran perlu dilakukan tes diagnosis sebagai bahan pertimbangan untuk perbaikan pertemuan-pertemuan berikutnya.

Saran yang dapat direkomendasikan dalam penelitian ini adalah yaitu : 1) Guru matematika hendaknya menerapkan model pembelajaran kooperatif tipe TPS sebagai alternatif dalam upaya perbaikan pembelajaran di kelas dan mengefektifkan pembelajaran matematika khususnya untuk meningkatkan kemampuan komunikasi matematika siswa.; 2) Penelitian mengenai model pembelajaran kooperatif tipe TPS pada materi Dimensi Tiga dapat ditindaklanjuti dengan menerapkan model pembelajaran TPS pada materi pokok lain, dan beberapa aspek lain seperti berpikir kreatif matematik, pemecahan masalah, dan lain sebagainya.

\section{Daftar Pustaka}

Ambarwati, Dwijanto, P Hendikawati. 2015. Keefektifan Model Project Based Learning Berbasis GQM terhadap Kemampuan Komunikasi Matematis dan Percaya Diri Siswa kelas VII. Unnes Journal of Mathematics Education 4 (2).

Anintya YA, E Pujiastuti, Mashuri. 2017. Analisis Kemampuan Matematis Ditinjau dari Gaya Belajar Siswa Kelas VII pada Model Pembelajaran Resourced Based 
Learning. Unnes Journal of Mathematics Education 6 (1). 2017.

Asikin, M. 2002. "Menumbuhkan Kemam-puan Matematika Melalui Pembelajaran Realistik". Jurnal Matematika atau Pembelajarannya (Prosiding Konferensi Nasional Matematika XI). 7, (Edisi Khusus), (492-496).

Baroody, A. J. 1993. "Problem Solving, Reasoning \& Communicating, K-8: Helping Children Think Mathematically". New York: McMillan Publishing Company.

Fauziah, ER Winarti, Kartono. 2017. Keefektifan Pembelajaran SAVI pada Pencapaian Kemampuan Komunikasi dan Disposisi Matematis Siswa Kelas VIII. Unnes Journal of Mathematics Education $6(1)$.

Huda, M. 2011. Cooperative Learning Metode, Teknik, Struktur dan Model Penerapan. Yogyakarta : Pustaka Pelajar.

Kabael, Tangul. 2012. Graduate Student Middle School Mathematics Teachers' Communication Abilities in the Language of Mathematics. Procedia Social and Behavioral Sciences 55 : 809 -815 .

Kearney, NE. 2009. Communication : A Vital Skill of Mathematics. Digital Commons. Lincoln : University of Nebraska.

Kitaoka, H. 2013. Teaching Methods that Help Economics Students to be Effective Problem Solvers. International Journal of Arts and Commerce.vol 2 No 1

Kosko, Karl W dan Wilkins, Jesse L. M. 2010. "Mathematical Communication and Its relation to the Frequency of Manipulative Use". International Electronics Journal of Mathematics Education-IEJME, 5 (2): 79-90.

Latifah NU, A Agoestanto. 2015. Keefektifan Model Pembelajaran AIR dengan Pendekatan RME terhadap Kemampuan Komunikasi Matematik Materi Geometri Kelas VII. Unnes Journal of Mathematics Education 4 (1).
Moleong, L.2005. Metodologi Penelitian Kualitatif. Bandung : Remaja Rosdakarya

NCTM. 1989. Curriculum and Evaluation Standards for School Mathematics. Reston VA : Authur.

2000. "Communication in Mathematics, -12 and Beyond". Reston, VA: NCTM. National Council of Teacher of Mathematics (NCTM). (2000). Principles and Standars for School Matematic. Reston, VA : NCTM.

Naim, N. 2011. Dasar-dasar Komunikasi Pendidikan. Jogjakarta : Ar-Ruzz Media.

Oktaviani, H Suyitno, Mashuri. 2015. Keefektifan Model Eliciting Activities Berbantuan LKPD terhadap Kemampuan Komunikasi Matematis dan Disposisi Matematis Peserta Didik Kelas VIII. Unnes Journal of Mathematics Education 5 (3).

Pandya, S. 2011. Interactive effect of cooperative learning model and learning goals of students on academic achievement of students in mathematics. Mevlana International Journal of Education (MIJE). Vol $1(2): 27-34$.

Permata CP, Kartono, Sunarni. 2015. Analisis Kemampuan Komunikasi Matematis Siswa Kelas VIII SMP pada Model Pembelajaran TSTS dengan Pendekatan Scientific. Unnes Journal of Mathematics Education 4 (2).

Prayitno,S. Suwarsono. \& Siswono,T. 2013. Komunikasi Matematis Siswa SMP dalam Menyelesaikan Soal Matematika Berjenjang Ditinjau dari Perberdaan Gender. Proceeding Seminar Nasional Matematika dan Pendidikan Matematik pada tanggal 9 November 2013 di Jurusan Pendidikan Matematika FMIPA UNY.

Putri L, Dwijanto, Sugiman. 2017. Analisis Kemampuan Matematis dan Rasa Percaya Diri Siswa SMK Kelas X pada Pembelajaran Geometri Model van Hiele Ditinjau dari Gaya Kognitif. Unnes Journal of Mathematics Education 6 (1). 
Rahmawati, A. 2017. "Analisis Kesalahan Mahasiswa Pendidikan Matematika Dalam Menyelesaikan Soal Pertidaksamaan Pada Mata Kuliah Kalkulus I". Al-Jabar : Jurnal Pendidikan Matematika, 81-90.

Sapto AD, H Suyitno, BE Susilo. 2015. Keefektifan Pembelajaran Strategi REACT dengan Model SSCS terhadap Kemampuan Komunikasi Matematika dan Percaya Diri Siswa Kelas VII. Unnes Journal of Mathematics Education 4 (3).

Setyaningsih L, M Asikin, S Mariani. 2016. Analisis Kemampuan Koneksi Matematika Siswa kelas VIII pada Model Eliciting Activities (MEA) Ditinjau dari Gaya Kognitif. Unnes Journal of Mathematics Education 5 (3)

Soeharto, K. 2008. Komunikasi Pembelajaran. Surabaya : Sic.
Sugiyono. 2013. Metode Penelitian Kombinasi (Mixed Methods). Bandung: Alfabeta.

Suwarto. 2013. Pengembangan Tes Diagnostik dalam Pembelajaran. Yogyakarta: Pustaka Pelajar

Sri Mukti Ayu Wandira, Indhira Asih VY, Aan Subhan Pamungkas. 2017. Prima : Jurnal Pendidikan Matematika. Vol. 1 No. 1 Juli 2017, hal 1-8.

Trianto. 2007. Model-model Pembelajaran Inovatif Berorientasi Konstruktivistik : Konsep, Landasan Teoristis-Praktis dan Implementasinya. Jakarta : Prestasi Pustaka Publisher.

Turmudi. 2008. Landasan Filsafat dan Teori Pembelajaran Matematika (Berparadigma Eksploratif dan Ivestigatif). Jakarta: Leuser Cita Pustaka.

Diakses tanggal 27 Maret 2007 dari http://www.udel.edu/chem/white/finalr pt.html. 